MacCallan was in England at the outbreak of the 1914 war, but at once returned to Egypt were he concentrated the travelling and tented hospitals at Alexandria as a general hospital for British and Australian sick and wounded. The static eye hospitals throughout the country were used for convalescent cases, though their out-patient departments were maintained as ophthalmic centres.

Later in the war MacCallan served as surgeon at a base hospital in Mersa Matruh, with the rank of Major, R.A.M.C. In 1920 he was made a C.B.E.

His work in Egypt provided MacCallan with unparalleled experience in the study of tropical diseases of the eye, and in particular of trachoma, on which he became a recognized world authority. In addition to many articles in the medical press, covering a wide field, he wrote a standard text-book on trachoma, and it was a fitting tribute to his work and to all that he had done to meet the ravages of this disease, that he was elected President of the International Trachoma Organization. From this position he only retired in September, 1954, after presiding over its activities during the XVII International Congress.

In 1923 MacCallan resigned from the service of the Egyptian Government. His great contributions to medicine in that country were recognized by two Egyptian decorations, and by the unique distinction of a bust of himself, presented by the ophthalmic surgeons of Egypt, which was unveiled by the High Commissioner in 1931.

Returning to England MacCallan proceeded to shape for himself a career as an ophthalmic surgeon in London. It was a striking tribute to his status, which he was proud to acknowledge, that in middle-age he was welcomed to the consulting staff of the Westminster Hospital and of the Royal Eye Hospital, to both of which, and to his private practice, he applied himself with customary zeal and enthusiasm. On reaching the age of retirement he continued research work at Westminster Hospital, and he resumed full clinical responsibility there during the war years.

MacCallan was a man of forceful character and incisive opinion, association with whom was always a stimulating and at times an exacting experience. Those of us who were privileged to work with him will remember him as a great clinician and teacher and as a pioneer and authority on the problems of trachoma. Some of us, too, will long cherish the memory of MacCallan as a host at his house in Welbeck Street, where his genial hospitality was abundant and his help and guidance freely given.

To Mrs. MacCallan, her daughter and two sons, deep sympathy will be extended from many quarters.

E. F. KING

\title{
MARIANO SORIA
}

WE regret to announce that Dr. Mariano Soria, Professor of Ophthalmology of the University of Barcelona and one of the best known ophthalmologists in Spain, died on March 30, 1955. Dr. Soria was president of the Jubilee Congress of the HispanoAmerican Congress in 1954.

\section{StePhen L. POLyaK}

Stephen L. Polyak, the greatest living authority on the anatomy of the visual system, died in Chicago on March 9, 1955, at the age of 65. He was born in Croatia and received his medical degree at the University of Zagreb. He was a health officer in the Serbian Army in the first world war. He taught neurology at the University of Zagreb from 1920 to 1928 , when he went to the United States. He was an assistant professor of neuroanatomy at the University of California, then went to the University of Chicago as an assistant professor of neurology in 1930. In 1938 he entered the antomy department and became Professor of Anatomy, when he began his research into the anatomy of the eye. His book on the retina is a classic, and before he died he had just finished a volume, "The Vertebrate Visual System ", to be published early in 1956. 